\title{
Commentary: Probiotic and technological properties of Lactobacillus spp. strains from the human stomach in the search for potential candidates against gastric microbial dysbiosis
}

\author{
Amit K. Tyagi* and Sahdeo Prasad \\ Cytokine Research Laboratory, Department of Experimental Therapeutics, The University of Texas MD Anderson Cancer \\ Center, Houston, TX, USA
}

Keywords: Lactobacillus reuteri, Helicobacter pylori, probiotics, inflammation, triple therapy

\section{A Commentary on}

Probiotic and technological properties of Lactobacillus spp. strains from the human stomach in the search for potential candidates against gastric microbial dysbiosis

OPEN ACCESS

Edited by:

Maria De Angelis,

University of Bari Aldo Moro, Italy

Reviewed by:

Ruggiero Francavilla,

University of Bari Aldo Moro, Italy

*Correspondence:

Amit K. Tyagi,

akumar6@mdanderson.org; amittyagiiitd@gmail.com

Specialty section:

This article was submitted to

Food Microbiology,

a section of the journal

Frontiers in Microbiology

Received: 30 December 2014 Accepted: 22 April 2015 Published: 19 May 2015

Citation:

Tyagi AK and Prasad S (2015)

Commentary: Probiotic and

technological properties of Lactobacillus spp. strains from the human stomach in the search for potential candidates against gastric

microbial dysbiosis.

Front. Microbiol. 6:433.

doi: 10.3389/fmicb.2015.00433 by Delgado, S., Leite, A. M. O., Ruas-Madiedo, P., and Mayo, B. (2014). Front. Microbiol. 5:766. doi: 10.3389/fmicb.2014.00766

Helicobacter pylori, a curved-shaped, flagellated, microaerophilic, gram-negative bacillus is naturally colonized bacteria in humans. This bacterium can be found in $25-50 \%$ of the population in developed countries and in 70-90\% in developing countries, probably, due to the poor hygiene (Go, 2002). New epidemiological studies revealed that the prevalence of $H$. pylori is declining. However, $H$. pylori-infected population develops various diseases including peptic ulcer, chronic gastritis, and gastric mucosa-associated lymphoid tissue (MALT) lymphoma (Ruggiero, 2014). It is the only bacterium that has been linked to the gastric cancer and ulcer disease, and thus associated with significant morbidity and mortality worldwide. Moreover, till now there is no universally effective therapeutic regimen and vaccine are available for the treatment of $H$. pylori associated diseases. Although triple therapy (combining acid suppression with clarithromycin, amoxicillin, or nitroimidazolic compounds) and antibiotics are being used against $H$. pylori infection, prolongation of these therapeutic agents is declining worldwide because of their side effects (such as vomiting, diarrhea, nausea, constipation, headache, etc.) (Yuan et al., 2013) and prevalence of antimicrobial resistance. $H$. pylori eradication treatments are still remain a challenge.

Extensive research on $H$. pylori and associated diseases concluded that probiotics can be used as an alternative or complementary therapy for the management of $H$. pylori infection (Emara et al., 2014), since it does not cause side effects as triple therapy. Probiotics have potential to maintain the disturbed gastroenterological conditions and also beneficial for the patients of inflammatory bowel disease, ulcerative colitis, Crohn's disease, antibiotic-, and rotavirus-associated diarrhea, adenocarcinoma, colorectal cancer, etc. (Goossens et al., 2003). An improvement of $H$. pylori associated gastric inflammation by the use of probiotics could be contributed by various mechanisms (Emara et al., 2014). Accumulated evidences suggested that $H$. pylori could be eradicated from the stomach by selective bacterial-bacterial cell interaction. Lactobacillus reuteri was identified as a highly specific binding antagonist to H. pylori among Lactobacillus species. L. reuteri DSM17648 strain co-aggregates with different $H$. pylori strains and serotypes. However, it does not affect other intestinal and commensal oral bacteria (Holz et al., 2015). 
How $L$. reuteri acts against $H$. pylori is not completely uncovered. However, it is reported that L. reuteri produces a compound called reuterin, which work as an antimicrobial agent. Other than reuterin, $L$. reuteri also produces some potent antimicrobial compounds, such as reutericin 6 and reutericyclin, but these have no effects on Gram-negative bacteria (Ganzle, 2004). L. reuteri also inhibits the binding of $H$. pylori to the putative glycolipid receptors. Mukai et al. (2002) examined the binding competition of $L$. reuteri strains, (JCM1081 and TM105) and $H$. pylori to gangliotetraosylceramide (asialo-GM1) and sulfatide. It was identified as a possible sulfatide-binding protein of the $L$. reuteri strain.

$L$. reuteri helps to improve the eradication rate of $H$. pylori induced by triple therapy (Table 1 ). In a recent clinical trial, it was observed that triple therapy supplemented with $L$. reuteri increased the eradication rate of $H$. pylori by $8.6 \%$, as well as reduced the side effects and improve the GSRS (Gastrointestinal Symptom Rating Scale) score (Emara et al., 2014). A new probiotic having two strains of L. reuteri (DSM 17938 and ATCC PTA 6475) were also studied for the inhibitory effect of $H$. pylori growth, gastritis and prevention of antibiotic-associated side effects, when administered with triple therapy. L. reuteri combination increased the eradication rate by $9.1 \%$ (Francavilla et al., 2014). Sequential therapy with $L$. reuteri supplementation was also reported in the eradication treatment of $H$. pylori and the intensity of antibiotic-associated side effects (Efrati et al., 2012). H. pylori infection was also defined as positive gastric histopathology ${ }^{13} \mathrm{C}$ urea breath test $\left({ }^{13} \mathrm{C}-\mathrm{UBT}\right)$. Dore et al. (2014) have done an open label single center study, where they found a significant reduction in urease activity with a difference of mean of 38.8 vs. 25.4 assessed before and 4-6 weeks post therapy. In another study, L. reuteri DSMZ17648 was also reported to co-aggregates with $H$. pylori in vitro and was shown to reduce ${ }^{13} \mathrm{C}$-UBT in vivo (Mehling and Busjahn, 2013).

Antibiotic-associated gastrointestinal side effects are major drawbacks of all $H$. pylori therapies. One of them is

\section{TABLE 1 | Selected clinical trials using Lactobacillus reuteri for $H$. pylori eradication treatment.}

\begin{tabular}{|c|c|c|c|c|}
\hline Treatment & Probiotic(s) & Eradication rate & Probiotic efficacy & References \\
\hline $\begin{array}{l}\text { Triple therapy, Omeprazole } \\
20 \mathrm{mg} \text {, amoxicillin } 1 \mathrm{~g} \text {, } \\
\text { clarithromycin } 500 \mathrm{mg}, 14 \mathrm{~d}\end{array}$ & $\begin{array}{l}\text { L. reuteri ATCC PTA 6475, } \\
\text { L. reuteri DSM 17938, } 14 \text { d } \\
\text { during therapy + further } 14 \\
\text { d, Control }\end{array}$ & $\begin{array}{l}74.3 \%(26 / 35) \\
65.7 \%(23 / 35) \\
\end{array}$ & $\begin{array}{l}\text { Non-significant increase of eradication rate with } \\
\text { improved GSRS score and reduction of side effects } \\
\text { (taste disorder, diarrhea) }\end{array}$ & Emara et al., 2014 \\
\hline $\begin{array}{l}\text { Three-phase study; } \\
\text { pre-eradication (1-28 d), } \\
\text { eradication ( } 29-35 \text { d), } \\
\text { follow-up (36-96 d), Triple } \\
\text { therapy }\end{array}$ & $\begin{array}{l}\text { L. reuteri ATCC PTA } 6475 \text {, } \\
\text { L. reuteri DSM } 17938, \\
\text { Control }\end{array}$ & $\begin{array}{l}75 \%(37 / 50) \\
65.9 \%(33 / 50) \\
\end{array}$ & $\begin{array}{l}\text { Non-significant increase of eradication rate but no } \\
\text { difference in GSRS score }\end{array}$ & Francavilla et al., 2014 \\
\hline $\begin{array}{l}\text { Pantoprazole } 20 \text { mg, } 8 \\
\text { weeks }\end{array}$ & L. reuteri, 8 weeks & $14.2 \%(3 / 21)$ & Good tolerability with no side effects & Dore et al., 2014 \\
\hline $\begin{array}{l}\text { Levofloxacin } 500 \text { mg, } \\
\text { esomeprazole } 20 \mathrm{mg} \text {, } \\
\text { amoxicillin } 1 \mathrm{~g}, 7 \mathrm{~d}\end{array}$ & $\begin{array}{l}\text { L. reuteri, during therapy }+ \\
\text { further } 7 \mathrm{~d} \text { Control }\end{array}$ & $\begin{array}{l}80 \%(36 / 45) \\
62.2 \%(28 / 45) \\
\end{array}$ & $\begin{array}{l}\text { Significantly increase of eradication rates and } \\
\text { reduction of side effects (Nausea, diarrhea) }\end{array}$ & Ojetti et al., 2012 \\
\hline $\begin{array}{l}\text { Omeprazole } 1 \mathrm{mg} / \mathrm{kg} \text {, } \\
\text { amoxicillin } 50 \mathrm{mg} / \mathrm{kg} \text {, } \\
\text { clarithromycin } 15 \mathrm{mg} / \mathrm{kg}, 7 \mathrm{~d}\end{array}$ & $\begin{array}{l}\text { L. plantarum, L. reuteri, L. } \\
\text { casei subsp. rhamnosus, B. } \\
\text { infantis, and B. longum, L. } \\
\text { acidophilus, L. salivarius, S. } \\
\text { thermophilus, L. } \\
\text { sporogenes, during therapy } \\
\text { Control }\end{array}$ & $\begin{array}{l}82.2 \%(30 / 34) \\
76.4 \%(26 / 34) \\
\end{array}$ & $\begin{array}{l}\text { Non-significant increase of eradication rates; } \\
\text { significant reduction of side effects (epigastric pain, } \\
\text { nausea, vomiting, diarrhea) }\end{array}$ & Tolone et al., 2012 \\
\hline $\begin{array}{l}\text { Pantoprazole } 20 \mathrm{mg}, \\
\text { amoxicillin } 1 \mathrm{~g}, \\
\text { clarithromycin } 500 \mathrm{mg}, \\
\text { Triple therapy, } 7 \mathrm{~d} \\
\text { Sequential regimen, } 10 \mathrm{~d}\end{array}$ & $\begin{array}{l}\text { L. reuteri ATCC55730, } \\
\text { during therapy + further } 7 \\
\text { or } 10 \mathrm{~d}\end{array}$ & $\frac{63 \%(52 / 83)}{88 \%(73 / 83)}$ & $\begin{array}{l}\text { Significantly higher eradication rate and reduction of } \\
\text { side effects in sequential regimen }\end{array}$ & Efrati et al., 2012 \\
\hline $\begin{array}{l}\text { Sequential therapy (Details } \\
\text { not describe) }\end{array}$ & $\begin{array}{l}\text { L. reuteri ATCC55730, } 8 \\
\text { weeks Control }\end{array}$ & $\begin{array}{l}33.8 \pm 15 \%(33) \\
35.8 \pm 15.5 \%(33) \\
\end{array}$ & Significant decrease in Gastrointestinal Symptom & Francavilla et al., 2008 \\
\hline $\begin{array}{l}\text { Triple therapy (Details not } \\
\text { describe) }\end{array}$ & L. reuteri, 7 d Control & $\begin{array}{l}63 \% \\
53 \% \\
\end{array}$ & Lowest incidence of side-effects & $\begin{array}{l}\text { Scaccianoce et al., } \\
2008\end{array}$ \\
\hline No drug & L. reuteri SD2112, 8 weeks & $\overline{69.7} \pm 4 \%(33)$ & Significant reduction of ${ }^{13} \mathrm{C}-U B T$ & Imase et al., 2007 \\
\hline $\begin{array}{l}\text { Omeprazole } 1 \text { mg/kg, } \\
\text { amoxicillin } 50 \text { mg/kg, } \\
\text { clarithromycin } 15 \text { mg/kg, } \\
\text { sequential therapy, } 10 \mathrm{~d}\end{array}$ & $\begin{array}{l}\text { L. reuteri ATCC55730 } \\
\text { (SD2112) Control }\end{array}$ & $\begin{array}{l}85 \%(17 / 20) \\
80 \%(16 / 20)\end{array}$ & Significant reduction of GSRS score & Lionetti et al., 2006 \\
\hline
\end{tabular}

GSRS, Gastrointestinal Symptom Rating Scale; ${ }^{13} \mathrm{C}-U B T ;{ }^{13} \mathrm{C}$ Urea Breath Test. 
levofloxacin-based second-line therapy. The efficacy of $L$. reuteri supplementation during a second-line levofloxacin triple therapy for H. pylori eradication was reported by Ojetti et al. (2012). In this study, The $H$. pylori eradication rate was significantly increased (18\%) and incidence of nausea and diarrhea was significantly lowered due to the $L$. reuteri supplementation. The therapeutic role of $L$. reuteri was also compared with a high concentration of probiotics for $H$. pylori eradication, where the incidence of side effects was lowest in 7-day therapy plus L. reuteri (6\%) treated group (Scaccianoce et al., 2008). These studies show that $L$. reuteri can be used as a complementary therapy for $H$. pylori infection. L. reuteri may compete directly with $H$. pylori, possibly by interference with adherence or by the production of antimicrobial molecules.

In a recent "Frontiers in Microbiology" paper by Delgado et al. (2014), authors isolated 10 strains of different Lactobacillus species from the gastric biopsies and stomach juice samples of healthy humans. These all strains were tested for their functional

\section{REFERENCES}

Delgado, S., Leite, A. M., Ruas-Madiedo, P., and Mayo, B. (2014). Probiotic and technological properties of Lactobacillus spp. strains from the human stomach in the search for potential candidates against gastric microbial dysbiosis. Front. Microbiol. 5:766. doi: 10.3389/fmicb.2014.00766

Dore, M. P., Cuccu, M., Pes, G. M., Manca, A., and Graham, D. Y. (2014). Lactobacillus reuteri in the treatment of Helicobacter pylori infection. Intern. Emerg. Med. 9, 649-654. doi: 10.1007/s11739-013-1013-Z

Efrati, C., Nicolini, G., Cannaviello, C., O'sed, N. P., and Valabrega, S. (2012). Helicobacter pylori eradication: sequential therapy and Lactobacillus reuteri supplementation. World J. Gastroenterol. 18, 6250-6254. doi: 10.3748/wjg.v18.i43.6250

Emara, M. H., Mohamed, S. Y., and Abdel-Aziz, H. R. (2014). Lactobacillus reuteri in management of Helicobacter pylori infection in dyspeptic patients: a doubleblind placebo-controlled randomized clinical trial. Therap. Adv. Gastroenterol. 7, 4-13. doi: 10.1177/1756283X13503514

Francavilla, R., Lionetti, E., Castellaneta, S. P., Magistà, A. M., Maurogiovanni, G., Bucci, N., et al. (2008). Inhibition of Helicobacter pylori infection in humans by Lactobacillus reuteri ATCC 55730 and effect on eradication therapy: a pilot study. Helicobacter 13, 127-134. doi: 10.1111/j.1523-5378.2008.00593.x

Francavilla, R., Polimeno, L., Demichina, A., Maurogiovanni, G., Principi, B., Scaccianoce, G., et al. (2014). Lactobacillus reuteri strain combination in Helicobacter pylori infection: a randomized, doubleblind, placebo-controlled study. J. Clin. Gastroenterol. 48, 407-413. doi: 10.1097/MCG.0000000000000007

Ganzle, M. G. (2004). Reutericyclin: biological activity, mode of action, and potential applications. Appl. Microbiol. Biotechnol. 64, 326-332. doi: 10.1007/s00253-003-1536-8

Go, M. F. (2002). Review article: natural history and epidemiology of Helicobacter pylori infection. Aliment. Pharmacol. Ther. 16(Suppl. 1), 3-15. doi: 10.1046/j.1365-2036.2002.0160s1003.x

Goossens, D., Jonkers, D., Stobberingh, E., van den Bogaard, A., Russel, M., and Stockbrugger, R. (2003). Probiotics in gastroenterology: indications and future perspectives. Scand. J. Gastroenterol. Suppl. 38, 15-23. 10.1080/00855920310002645

Holz, C., Busjahn, A., Mehling, H., Arya, S., Boettner, M., Habibi, H., et al. (2015). Significant reduction in Helicobacter pylori load in humans with non-viable Lactobacillus reuteri DSM17648: a pilot study. Probiotics Antimicrob. Proteins. 7, 91-100. doi: 10.1007/s12602-014-9181-3

Imase, K., Tanaka, A., Tokunaga, K., Sugano, H., Ishida, H., and Takahashi, S. (2007). Lactobacillus reuteri tablets suppress Helicobacter pylori infection-a double-blind randomised placebo-controlled properties, like bile tolerance, acid resistance, adhesion to epithelial gastric cells, production of antimicrobial compounds, antioxidative activity, antibiotic resistance, carbohydrate fermentation, glycosidic activities, and inhibition of $H$. pylori. In vitro, two gastric strains (particularly LR32 and LR34) showed good survival under gastrointestinal conditions, along with strong anti-Helicobacter and antioxidative activities. Thus, these strains can be considered as promising probiotic candidates.

The data presented have important implications for different disciplines including gastroenterology, microbial ecology, colorectal cancer, nutrition and health. Thus, based on these findings following intriguing questions can be raised: (1) To what extent $L$. reuteri is helpful for the prevention of $H$. pyloriinduced colorectal cancer? (2) If it is available in our stomach or gut, how $L$. reuteri population can be increased inside the gut? (3) What could be the other potential probiotics and nutraceuticals, which can synergize the growth of $L$. reuteri in the gut?

cross-over clinical study. Kansenshogaku Zasshi 81, 387-393. doi: 10.11150/kansenshogakuzasshi1970.81.387

Lionetti, E., Miniello, V. L., Castellaneta, S. P., Magistá, A. M., de Canio, A., Maurogiovanni, G., et al. (2006). Lactobacillus reuteri therapy to reduce sideeffects during anti-Helicobacter pylori treatment in children: a randomized placebo controlled trial. Aliment. Pharmacol. Ther. 24, 1461-1468. doi: 10.1111/j.1365-2036.2006.03145.x

Mehling, H., and Busjahn, A. (2013). Non-viable Lactobacillus reuteri DSMZ 17648 (Pylopass) as a new approach to Helicobacter pylori control in humans. Nutrients 5, 3062-3073. doi: 10.3390/nu5083062

Mukai, T., Asasaka, T., Sato, E., Mori, K., Matsumoto, M., and Ohori, H. (2002). Inhibition of binding of Helicobacter pylori to the glycolipid receptors by probiotic Lactobacillus reuteri. FEMS Immunol. Med. Microbiol. 32, 105-110. doi: 10.1111/j.1574-695X.2002.tb00541.x

Ojetti, V., Bruno, G., Ainora, M. E., Gigante, G., Rizzo, G., Roccarina, D., et al. (2012). Impact of Lactobacillus reuteri supplementation on antiHelicobacter pylori levofloxacin-based second-line therapy. Gastroenterol. Res. Pract. 2012:740381. doi: 10.1155/2012/740381

Ruggiero, P. (2014). Use of probiotics in the fight against Helicobacter pylori. World J. Gastrointest. Pathophysiol. 5, 384-391. doi: 10.4291/wjgp.v5.i4.384

Scaccianoce, G., Zullo, A., Hassan, C., Gentili, F., Cristofari, F., Cardinale, V., et al. (2008). Triple therapies plus different probiotics for Helicobacter pylori eradication. Eur. Rev. Med. Pharmacol. Sci. 12, 251-256.

Tolone, S., Pellino, V., Vitaliti, G., Lanzafame, A., and Tolone, C. (2012). Evaluation of Helicobacter Pylori eradication in pediatric patients by triple therapy plus lactoferrin and probiotics compared to triple therapy alone. Ital. J. Pediatr. 38:63. doi: 10.1186/1824-7288-38-63

Yuan, Y., Ford, A. C., Khan, K. J., Gisbert, J. P., Forman, D., Leontiadis, G. I., et al. (2013). Optimum duration of regimens for Helicobacter pylori eradication. Cochrane Database Syst. Rev. 12:CD008337. doi: 10.1002/14651858.CD008337.pub2

Conflict of Interest Statement: The authors declare that the research was conducted in the absence of any commercial or financial relationships that could be construed as a potential conflict of interest.

Copyright (c) 2015 Tyagi and Prasad. This is an open-access article distributed under the terms of the Creative Commons Attribution License (CC BY). The use, distribution or reproduction in other forums is permitted, provided the original author(s) or licensor are credited and that the original publication in this journal is cited, in accordance with accepted academic practice. No use, distribution or reproduction is permitted which does not comply with these terms. 